\title{
Characterization of a fluoride-resistant bacterium Acinetobacter sp. RH5 towards assessment of its water defluoridation capability
}

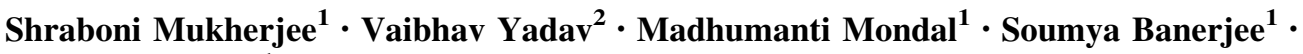 \\ Gopinath Halder ${ }^{1}$
}

Received: 19 June 2015/Accepted: 3 December 2015/Published online: 18 December 2015

(C) The Author(s) 2015. This article is published with open access at Springerlink.com

\begin{abstract}
The present study investigates the defluoridation capability of fluoride-resistant bacteria from contaminated groundwater collected from Asanjola and Madhabpur, West Bengal, India. Seven strains of fluorideresistant bacteria were isolated employing culture media containing $10-250 \mathrm{mg} / \mathrm{L}$ of fluoride to evaluate their ability in reducing fluoride concentration in water. Five isolates exhibited significant amount of reduction in fluoride. Isolate RH5 achieved a maximum fluoride removal of $25.7 \%$ from the media at $30{ }^{\circ} \mathrm{C}$ and $\mathrm{pH} 7$ after 8 days of incubation. Based on morphological, physiological characteristics and analysis of 16S rDNA gene sequence, isolate RH5 was identified as Acinetobacter sp. RH5. Growth of RH5 was analysed at a diverse $\mathrm{pH}$ range, and it could thrive at $\mathrm{pH} 5-10$. The present investigation revealed that the selective pressure of fluoride results in growth of fluoride-resistant bacteria capable of secreting high-affinity anion-binding compounds. This bacterium played a dominant bioremediative role by concentrating the anions so that they become less available. Hence, the fluoride-resistant bacteria, Acinetobacter sp. RH5, could be used as a promising strain for application in water defluoridation from contaminated sites.
\end{abstract}

Keywords Bioremediation - Defluoridation ·

Xenobiotic $\cdot$ Characterization $\cdot$ Acinetobacter

Gopinath Halder

gopinath_haldar@yahoo.co.in

1 Department of Chemical Engineering, National Institute of Technology, Durgapur, West Bengal, India

2 Department of Earth and Environmental Studies, National Institute of Technology, Durgapur, West Bengal, India

\section{Introduction}

Trace elements have toxic effects when their level of permissibility is exceeded. The permissible limits for the discharge of toxic metals into the water bodies have been prescribed by various regulatory bodies (Sud et al. 2008). The health hazards and environmental degradation caused due to addition of the metal ions at a much higher concentration than the permissible limits are given in Table 1 . For example, the fluoride ion has got some side effects which are toxic to the protoplasmic content of the cell affecting its biochemical content when its levels exceed $1.5 \mathrm{mg} / \mathrm{L}$ in drinking water (Annadurai et al. 2014).

Fluorine accounts for almost $0.3 \mathrm{~g} / \mathrm{kg}$ of the earth's crust and exists in the form of fluoride in minerals such as fluorspar, cryolite and fluorapatite (Ghosh et al. 2013). The permissible limit for fluoride in drinking water as prescribed by World Health Organization (WHO), Indian Standard (IS), US Environment Protection Agency (USEPA) and European Union (EU) is 1.5, 1.0, 4 and $1.5 \mathrm{mg} / \mathrm{L}$, respectively, with a target of between 0.8 and $1.2 \mathrm{~g} / \mathrm{L}$ to maximize benefits and minimize adverse effects (WHO 2006; Edmunds and Smedley 2013). The effects of varying concentrations of fluoride on human health are given in Table 2.

In recent years, high levels of fluoride in groundwater (McDonagh et al. 2000) have resulted in vitiation of water quality, which has led to widespread anxiety. In West Bengal, India, excess amount of fluoride in groundwater has been detected across seven districts, viz. Purulia, Birbhum, Bankura, Malda, South Dinajpur, North Dinajpur and South 24-Parganas. Literature review by Bhattacharya and Chakrabarti (2011) confirms the existence of fluoride as a complex ion in a naturally occurring mineral called apatite which is a fluorinated calcium phosphatic

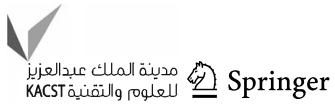


Table 1 Permissible limits and health effects of various toxic heavy metals

\begin{tabular}{|c|c|c|c|c|c|c|}
\hline $\begin{array}{l}\text { Metal } \\
\text { contaminants }\end{array}$ & $\begin{array}{l}\text { IS: } 2490 \\
(1974) \\
\text { For surface } \\
\quad \text { water }(\mathrm{mg} / \mathrm{L})\end{array}$ & $\begin{array}{l}\text { IS: } 3306(1974) \text { for } \\
\text { public sewers }(\mathrm{mg} / \mathrm{L})\end{array}$ & $\begin{array}{l}\text { IS: } 3307(1974) \text { for } \\
\text { irrigation }(\mathrm{mg} / \mathrm{L})\end{array}$ & $\begin{array}{l}\text { WHO } \\
(\mu \mathrm{g} / \mathrm{L})\end{array}$ & $\begin{array}{l}\text { USEPA } \\
(\mu \mathrm{g} / \mathrm{L})\end{array}$ & Adverse health effects \\
\hline Arsenic & 0.20 & 0.20 & 0.20 & 10.00 & 50.00 & $\begin{array}{l}\text { Carcinogenic, liver tumours, skin and } \\
\text { gastrointestinal effects }\end{array}$ \\
\hline Mercury & 0.01 & 0.01 & - & 1.00 & 2.00 & $\begin{array}{l}\text { Dermatitis, anorexia, kidney damage and } \\
\text { muscle pain }\end{array}$ \\
\hline Cadmium & 2.00 & 1.00 & - & 3.00 & 5.00 & $\begin{array}{l}\text { Carcinogenic, lung fibrosis, dyspnoea and } \\
\text { weight loss }\end{array}$ \\
\hline Lead & 0.10 & 1.00 & - & 10.00 & 5.00 & $\begin{array}{l}\text { Loss of appetite, anaemia, sterility, kidney } \\
\text { problem, high blood pressure }\end{array}$ \\
\hline Chromium & 0.10 & 2.00 & - & 50.00 & 100.00 & Lung tumours, allergic dermatitis \\
\hline Nickel & 3.00 & 3.00 & - & - & - & $\begin{array}{l}\text { Chronic bronchitis, lung cancer, nasal } \\
\text { sinus }\end{array}$ \\
\hline Zinc & 5.00 & 15.00 & - & - & - & Metal fume fever, restlessness \\
\hline Copper & 3.00 & 3.00 & - & - & 1300.00 & $\begin{array}{l}\text { Irritation of nose, mouth, eyes, headache } \\
\text { diarrhoea }\end{array}$ \\
\hline Fluoride & 1.0 & 1.0 & - & 0.0015 & 0.004 & Dental fluorosis, skeletal fluorosis \\
\hline
\end{tabular}

Table 2 Effects of varying concentrations of fluoride on human health

\begin{tabular}{ll}
\hline Level in water & Effects \\
\hline Nil & $\begin{array}{l}\text { Limited growth and fertility } \\
0.8-1.2 \mathrm{mg} / \mathrm{L}\end{array}$ \\
$\begin{array}{l}\text { Prevention of tooth decay, strengthening } \\
\text { of skeleton } \\
\text { Above } 1.5 \mathrm{mg} / \mathrm{L}\end{array}$ & $\begin{array}{c}\text { Fluorosis: pitting of tooth enamel and } \\
\text { deposits in bones } \\
\text { Crippling skeletal fluorosis }\end{array}$ \\
\hline
\end{tabular}

compound. It has been observed from experimental investigations that various physico-chemical factors are found to be responsible for fluoride contamination of water from the fluoride-bearing rock into the saturated zone of groundwater (Datta et al. 2014). Analysis of water samples revealed that the presence of $\mathrm{Na}-\mathrm{K}-\mathrm{Ca}-\mathrm{Mg}-\mathrm{HCO}_{3}$ favours continuous erosion from the fluoride-rich host rock under alkaline $\mathrm{pH}$ condition of the circulating water as revealed by Saxena and Ahmed (2003). Due to highly fragile economic structure, the absence of any treatment or monitoring systems the rural populace is compelled to drink fluoride contaminated water in these places (Singh et al. 2001). Fluoride is an oligo-element indispensable to bone and teeth development when ingested below the specified limit of $1.5 \mathrm{mg} / \mathrm{L}$ (Li et al. 2001; Susheela 1999) but poses a threat to human health when the prescribed limit is breached. Fluoride intake in excess leads to dental, skeletal and non-skeletal fluorosis (Gopalakrishnan et al. 1991; Zhu et al. 2006). It has been reported to be endemic in 20 countries of the world (Messaitfa 2008) with 22 states of
India bearing the brunt of fluoride contamination (Susheela 1999). Several methods have been reported to treat fluoride contaminated water such as osmosis, nanofiltration, electrodialysis, precipitation and adsorption. These methods have certain drawbacks like secondary pollution, high sludge generation and high capital investment. The advantages of biological processes are functional simplicity, cost-effectiveness, less sludge production, facile regeneration of the biomass. Microbes have the capability of developing resistance to their surroundings through several processes such as bioaccumulation, biotransformation and biosorption (Juwarkar and Yadav 2010) since the bacterial cell wall comprises metal binding groups like amines, carboxylates, sulfhydryl and phosphates which aid in the interaction of metal ions (Kleinubing et al. 2011; Wuertz and Mergeay 1997). Biological degradation of petroleum wastes has been reported by bacteria of the genus Pseudomonas (Chung et al. 2003), Sphingomonas (Liu et al. 2009) and Acinetobacter (Ahmad et al. 2012). Acinetobacter strains have been explored for degradation of persistent organic pollutants (POPs) like atrazine (Cail et al. 2003). In 2012, five fluoride-resistant strains were isolated and a maximum fluoride removal of $22.1 \%$ was achieved by Pseudomonas aerugenosa (Chouhan et al. 2012). Table 3 gives a comparative study of fluoride removal by processes other than bioremediation.

A freshwater unicellular microbial species, Acinetobacter sp. RH5, was isolated from Asanjola, India. The aim was to characterize fluoride-resistant bacterial strains from oligotrophic and heterotrophic niches and to utilize these strains towards defluoridation of contaminated water. 
Table 3 Comparative study of fluoride removal by various techniques

\begin{tabular}{llll}
\hline S1. no. & Techniques & $\%$ Removal of fluoride/adsorption capacity & References \\
\hline 1. & Adsorption by activated alumina & $69.5 \%$ & Ghorai and Pant (2005) \\
2. & Adsorption by carbon materials $\mathrm{KMnO}_{4}$ modified activated carbon & $15.9 \mathrm{mg} / \mathrm{g}$ & Daifullah et al. (2007) \\
3. & Co-precipitation (Nalgonda technique) & $2.1-0.7 \mathrm{mg} / \mathrm{L}$ & Dahi et al. (1996) \\
4. & Precipitation with calcium and phosphate compounds & $15 \mathrm{mg} / \mathrm{L}$ & Saha (1993) \\
5. & Ion exchange (modified zeolite) & $94 \%$ & Samatya et al. (2007) \\
6. & Reverse osmosis & $98.9 \%$ & Diawara et al. (2011) \\
7. & Nanofiltration & & Diawara et al. (2011) \\
& Brackish water & $63.3 \%$ & Pandey et al. (2012) \\
8. & Fluorinated drinking water & $71 \%$ & Halder et al. (2014) \\
9. & Biosorption (powdered biomass Tinospora cordifolia) & $25 \mathrm{mg} / \mathrm{g}$ & Chouhan et al. (2012) \\
10. & Bioremediation (Pseudomonas aerugenosa) & $70 \%$ & Present study \\
11. & Bioremediation (Acinetobacter RH5) & $22.1 \%$ & $25.7 \%$ \\
\hline
\end{tabular}

\section{Materials and methods}

\section{Sample collection and fluoride concentration measurement}

Asanjola and Madhabpur villages in Rampurhat tehsil $\left(24.17^{\circ} \mathrm{N}, 87.78^{\circ} \mathrm{E}\right)$, Birbhum district, West Bengal, India, were selected for collecting the samples as this district is known to be endemic to fluoride where the rural population is dependent only on groundwater resources for their daily consumption (Susheela 1999). Due to highly fragile economic structure, the absence of any treatment or monitoring systems causes the rural populace to drink fluoride contaminated water in these villages; $50 \mathrm{~mL}$ of water samples was collected in presterilized containers and analysed for their fluoride concentration.

A fluoride ion-selective electrode (Orion, Thermo Scientific, USA) was employed for measuring the fluoride concentration of water samples. Calibration of the instrument was performed with standard solutions containing fluoride concentrations of $0.1,1,10$ and $100 \mathrm{ppm}(\mathrm{mg} / \mathrm{L})$. A total ionic strength adjustment buffer (TISAB) was added to each sample before measuring the fluoride concentration to equalize the $\mathrm{pH}$ and ionic strength of the samples and the standards. It also facilitates removal of any interference by $\mathrm{Fe}(\mathrm{III})$ and $\mathrm{Al}(\mathrm{III})$ by forming a complex with these ions, hence releasing fluoride ions into the solution (Schamschula et al. 1985; NIOSH 1994).

\section{Isolation and adaptation of bacterial cultures on media containing sodium fluoride}

All the glassware was acid washed with $10 \%$ hydrochloric acid prior to use. The collected water samples were allowed to stand at room temperature for $3 \mathrm{~h}$ to permit sedimentation of debris. Luria-Bertani (LB) medium with $2 \%$ agar was used for plating and was sterilized by autoclaving at $121{ }^{\circ} \mathrm{C}$ and 15 psi pressure for $15 \mathrm{~min} ; 100 \mu \mathrm{L}$ of the supernatant was inoculated on plates containing sterilized LB agar media using spread plate technique and incubated for $24 \mathrm{~h}$ at $30{ }^{\circ} \mathrm{C}$. Petri plates exhibiting bacterial growth were selected, and distinct colonies were streaked on a new set of LB agar media and incubated for $24 \mathrm{~h}$ at $30{ }^{\circ} \mathrm{C}$.

LB agar media containing $10 \mathrm{mg} / \mathrm{L}$ fluoride was prepared using sodium fluoride $(\mathrm{NaF})$, and the bacterial cultures were streaked onto these plates. It was followed by incubation of these plates at $30{ }^{\circ} \mathrm{C}$ for $24 \mathrm{~h}$. Resistant micro-organisms were inoculated in LB broth containing the same concentration of fluoride as in the source plate media and incubated for $24 \mathrm{~h}$ at $30^{\circ} \mathrm{C}$ in a rotary shaker at $120 \mathrm{rpm}$. Low concentration of fluoride was initially selected to allow the culture micro-organisms to adapt on media containing fluoride and to prevent inhibition of growth (Zhang et al. 2013). The microbes were then subjected to an increased fluoride concentration when broth cultures were further subcultured on LB agar plates containing $50 \mathrm{mg} / \mathrm{L}$ fluoride concentration, followed by incubation and then inoculation in LB broth containing $50 \mathrm{mg} /$ $\mathrm{L}$ of fluoride. The same procedure was repeated for media containing $150 \mathrm{mg} / \mathrm{L}$ and $250 \mathrm{mg} / \mathrm{L}$ fluoride. After three subcultures, isolated bacterial cultures were obtained.

\section{Determination of strain performance and selection of initial pH of selective medium}

In order to determine the fluoride degrading capability, the isolated strains were inoculated in $250-\mathrm{mL}$ conical flasks in triplicates containing LB broth with $20 \mathrm{mg} / \mathrm{L}$ fluoride concentration and incubated at $30{ }^{\circ} \mathrm{C}$ on a rotary shaker at 
$120 \mathrm{rpm}$. Broth containing $20 \mathrm{mg} / \mathrm{L}$ fluoride was selected due to the reason that maximum fluoride concentration in contaminated groundwater was observed to be $19.2 \mathrm{mg} / \mathrm{L}$. Samples were taken from these flasks and analysed for fluoride concentration and growth. Ten millilitres of sample was taken at a time for fluoride analysis and centrifuged at $4500 \mathrm{rpm}$ for $15 \mathrm{~min}$, and the supernatant was subjected to fluoride concentration analysis using a fluoride ion-selective electrode. The bacterial isolate designated as RH5 showing the maximum fluoride removal percentage was chosen, and effects of initial $\mathrm{pH}$ on growth in LB broth were studied for this isolate. Initial $\mathrm{pH}$ was adjusted to 5, 6, $7,8,9$, and 10 , respectively, by adding $0.1 \mathrm{~mol} / \mathrm{L}$ sodium hydroxide or $0.1 \mathrm{~mol} / \mathrm{L}$ hydrochloric acid solutions. Study of bacterial growth by means of spectrophotometric analysis at $600 \mathrm{~nm}$ gave the optimum $\mathrm{pH}$ for the isolate RH5.

\section{Biochemical characterization and growth kinetics of isolate RH5}

\section{Methyl red test}

The methyl red test was conducted to verify the ability of isolate RH5 to perform mixed acid fermentation (Palitzsch 1911; MacFaddin 1980); $100 \mu \mathrm{L}$ of inoculum of isolate RH5 was inoculated in a tube containing MRVP (methyl red Voges-Proskauer) broth and incubated at $35^{\circ} \mathrm{C}$ for $24 \mathrm{~h}$. Five drops of methyl red were added after incubation, and the result was recorded. A red colour change indicated the presence of mixed acid fermentation.

\section{Voges-Proskauer test}

Voges-Proskauer test was performed to determine whether the isolate RH5 produced 2,3-butanediol as a fermentation product from glucose. Since 2,3-butanediol cannot be easily detected, the test targets acetoin, which is an intermediate in the pathway. An inoculum from a culture of isolate RH5 was inoculated in a tube containing MRVP (methyl red Voges-Proskauer) broth and incubated for $24 \mathrm{~h}$ at $35^{\circ} \mathrm{C}$. Five drops of Barritt's A reagent were added to the tube after incubation followed by addition of five drops of Barritt's B reagent. The tube was then allowed to stand in a slant position for half an hour. Development of red colour indicated a positive test (MacFaddin 1980).

\section{Catalase test}

This test was accomplished using the method of Evans and Kloos (1972). A sterile inoculating loop was used to collect a single 24-h-old colony of isolate RH5 culture from LB agar medium and placed on a slide. A single drop of $3 \%$ $\mathrm{H}_{2} \mathrm{O}_{2}$ was placed on the smear and covered with a petri plate. The presence of catalase was signified by the formation of bubbles.

\section{Oxidase test}

Overnight grown individual colonies were removed using a sterile, plastic loop. The cells were rubbed onto a moistened strip impregnated with oxidase reagent $(1 \%$ $N, N, N, N$-tetramethyl $p$-phenylenediamine dihydrochloride). This chemical replaces oxygen as a recipient for the electrons from the oxidase cytochrome. The additional electrons turn the oxidase reagent from colourless to purple. If oxidase is not present, no colour change is observed.

\section{Nitrate reduction test}

Nitrate reduction test was executed to determine the ability of the isolate to reduce nitrate to nitrite using the enzyme nitrate reductase. Nitrate broth containing nutrients and potassium nitrate was inoculated with the test micro-organism. A second tube containing only uninoculated nitrate broth was used as control. Both inoculated and control tubes were incubated for $24 \mathrm{~h}$ at $30{ }^{\circ} \mathrm{C}$. After incubation, a drop of reagent A $(0.8 \mathrm{~g}$ sulfanilic acid and $100 \mathrm{~mL} 30 \%$ acetic acid) and reagent $\mathrm{B}$ (500 mg N,N-dimethyl-1-naphthylamine and $100 \mathrm{~mL} 30 \%$ acetic acid) each was added. Then a small amount of powdered zinc was added and results were recorded. Development of red colour after the addition of sulfanilic acid and $N, N$-dimethyl-1-naphthylamine, followed by its disappearance on addition of zinc, indicates a positive result. Appearance of no colour after the addition of the same reagents followed by appearance of red colour on addition of zinc indicates a negative result.

A spectrophotometer (UV-2300, Techcomp Ltd., Singapore) was employed to measure the growth of isolate RH5 in LB broth. Absorbance of the bacterial isolate was measured at $600 \mathrm{~nm}$ at intervals of $4 \mathrm{~h}$. The absorbance readings were then plotted against time to determine the growth phases and to establish a link between fluoride removal and growth of the isolate RH5 (Campbell et al. 2006).

\section{Identification and phylogenetic analysis of isolate RH5}

Identification by means of $16 \mathrm{~S}$ rDNA sequencing was carried out for identification of isolate RH5. Genomic DNA was isolated from the plate culture of isolate RH5 using AMpurE Bacterial Genomic DNA Mini kit (Amnion Biosciences Pvt. Ltd., India). Using consensus/universal oligos, the $\sim 1.5-\mathrm{kb} 16 \mathrm{~S}$ rDNA fragment from isolated gDNA was amplified using Taq DNA polymerase, employing the primers 5'-CWG RCC TAN CAC ATG SAA GTC and 5'GRC GGW GTG TAC NAG GC $(\mathrm{R}=\mathrm{A}$ or $\mathrm{G} ; \mathrm{S}=\mathrm{C}$ or 
$\mathrm{G} ; \mathrm{W}=\mathrm{A}$ or $\mathrm{T} ; \mathrm{N}=\mathrm{A}$ or $\mathrm{C}$ or $\mathrm{G}$ or $\mathrm{T} ; \mathrm{W}=\mathrm{A}$ or $\mathrm{T})$. In brief, the PCRs (polymerase chain reaction) were performed under the following set of conditions: 35 cycles of denaturation at $94{ }^{\circ} \mathrm{C}$ for $30 \mathrm{~s}$, annealing at $55^{\circ} \mathrm{C}$ for $30 \mathrm{~s}$ and extension at $72{ }^{\circ} \mathrm{C}$ for $1 \mathrm{~min} 30 \mathrm{~s}$. Sanger dideoxy sequencing was performed by using BigDye Terminator v.3.1 Cycle Sequencing kits (Applied Biosystems, USA). Purified cycle sequencing products were analysed on an ABI Prism 3130 xl Genetic Analyzer. The PCR product was bi-directionally sequenced using the forward, reverse and/or an internal oligos. The PCR product was loaded on $1.0 \%$ agarose gel along with a 500-bp DNA ladder (Amnion Biosciences Pvt. Ltd., India). Sequence data were aligned and analysed for finding the closest homologous micro-organisms using nucleotide Basic Local Alignment Search Tool (NCBI-blastn).

\section{Results and discussion}

\section{Fluoride concentration of samples}

Water samples from Asanjola were highly contaminated with fluoride with 3 out of 4 groundwater samples containing fluoride concentration above $15 \mathrm{mg} / \mathrm{L}$. The rock types present in the areas surrounding Asanjola are mainly composed of biotite which itself produces dissolved fluoride concentrations beyond $4 \mathrm{mg} / \mathrm{L}$ (Gupta et al. 2012). Madhabpur fared a little better with only one sample exceeding the prescribed fluoride limit. In the preliminary experiments, we found that isolate RH5 could grow in $100 \mathrm{mg} / \mathrm{L}$ of $\mathrm{NaF}$ and possess the ability of accumulating large amounts of fluoride. But, there are no systematic studies regarding the application of this strain for the defluoridation of water (Table 4).

\section{Strain isolation and adaptation on media containing fluoride}

A total of seven bacterial isolates were obtained from samples collected from Rampurhat. The isolates were

Table 4 Fluoride concentration of samples of Asanjola and Madhabpur

\begin{tabular}{lll}
\hline Area & Sites & Fluoride concentration $(\mathrm{mg} / \mathrm{L})$ \\
\hline Asanjola & Hand pump1 & 19.2 \\
& Primary school & 15.4 \\
& Hand pump2 & 19.0 \\
& Pond & 0.512 \\
Madhabpur & Primary school & 16.3 \\
& Hand pump & 0.418 \\
& Pond & 0.630 \\
\hline
\end{tabular}

labelled as VF1, VF2, VF3, VF4, VF5, R3 and RH5. These isolates were differentiated on the basis of their colony characteristics and subjected to Gram staining. The isolated strains were subjected to different fluoride concentrations and all exhibited growth till $100 \mathrm{mg} / \mathrm{L}$ of fluoride concentration after incubation at $30{ }^{\circ} \mathrm{C}$ for $24 \mathrm{~h}$. The resistant isolates were then inoculated in LB broth with the same concentration of fluoride. Five isolates were able to withstand maximum fluoride concentrations up to $250 \mathrm{mg} / \mathrm{L}$.

\section{Identification of strain performance and determination of initial $\mathrm{pH}$ of selective medium}

All of the isolates were analysed for fluoride reduction capability by measuring fluoride concentration of the broth after centrifugation at $4500 \mathrm{rpm}$ for $15 \mathrm{~min}$. Percentage reduction in fluoride content was determined for each alternate day, viz. days $0,2,4,6,8$ and 10. Reduction in fluoride concentration was observed till day 8 after which there was no considerable defluoridation which can be attributed to reduction in cell viability. Isolates VF1, VF4, VF5, R3 and RH5 exhibited significant fluoride removal. Isolates VF2 and VF3 were not able to remove fluoride in significant amounts. Isolate RH5 obtained from water sample taken from Asanjola showed the maximum fluoride reducing capability of $25.7 \%$ and was selected for identification and characterization. The growth of isolate RH5 can be due to high levels of fluoride which might produce a situation closer to that of using an antibacterial agent, in which a resistant organism is released from ecological restrictions of the community and can, therefore, grow in higher levels in the presence of fluoride. Previously, bacterial species have been reported to achieve a maximum of $22.1 \%$ fluoride removal ( $\mathrm{Xu}$ et al. 2011). Initial $\mathrm{pH}$ of medium was adjusted to $5,6,7,8,9$ and 10, respectively, to study the growth of the isolate and uptake of fluoride by the isolated strain. The absorbance recorded at $600 \mathrm{~nm}$ was least for $\mathrm{LB}$ broth at $\mathrm{pH} 10$ and maximum for $\mathrm{pH} 7$ which is shown in Fig. 1. Therefore, $\mathrm{pH} 7$ was deemed to be the optimum for growth of isolate RH5 (Table 5).

\section{Biochemical characterization and growth kinetics of isolate RH5}

Isolate RH5 obtained from water sample taken of Asanjola, Rampurhat, is a Gram negative, non-motile, coccobacillary bacterium. It is oxidative and aerobic in nature. The strain could grow at a diverse range of $\mathrm{pH}(\mathrm{pH} 5-10)$ conditions, with optimum $\mathrm{pH}$ being 7 . It could produce acid from galactose, glucose and maltose but not from mannitol and sucrose. The strain tested negative for methyl red, VogesProskauer, oxidase and nitrate reduction tests and positive for catalase test. 
Fig. 1 Effect of $\mathrm{pH}$ on growth of Acinetobacter sp. RH5; the bacterium was able to thrive on a diverse $\mathrm{pH}$ range

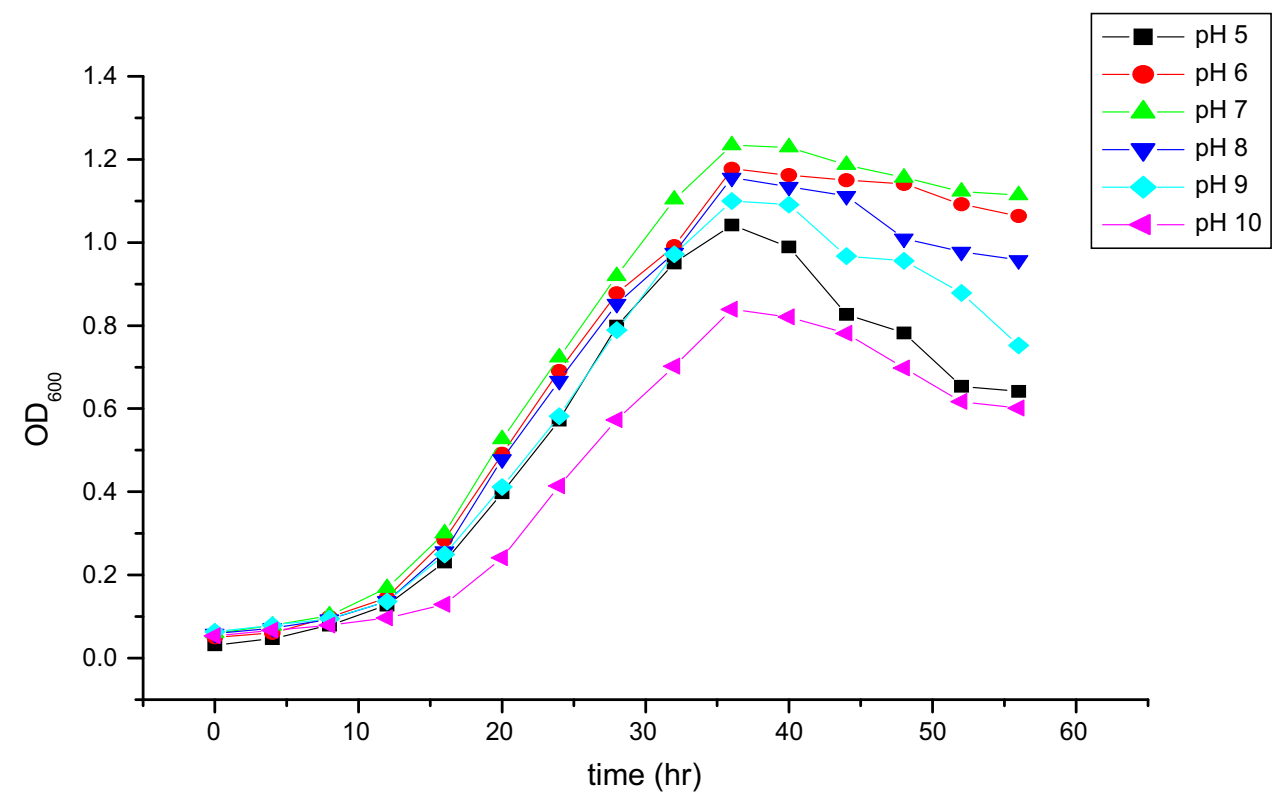

Table 5 Percentage reduction in fluoride by isolates

\begin{tabular}{lllccr}
\hline Isolate & \multicolumn{5}{l}{ Fluoride reduction $(\%)$} \\
\cline { 2 - 6 } & Day 0 & Day 2 & Day 4 & Day 6 & Day 8 \\
\hline VF1 & 0.0 & 4.5 & 7.2 & 9.1 & 15.7 \\
VF2 & 0.0 & 1.6 & 2.7 & 3.7 & 5.1 \\
VF3 & 0.0 & 2.1 & 3.9 & 5.1 & 7.4 \\
VF4 & 0.0 & 8.5 & 14.7 & 16.8 & 20.5 \\
VF5 & 0.0 & 7.6 & 12.6 & 14.2 & 19.1 \\
R3 & 0.0 & 6 & 11.4 & 17.4 & 18.5 \\
RH5 & 0.0 & 9.5 & 18.1 & 21 & 25.7 \\
\hline
\end{tabular}

The strain RH5 exhibited a diminutive lag phase, lasting for only $6 \mathrm{~h}$, implying its ability to adapt to the medium of high fluoride concentration. After $6 \mathrm{~h}$, the strain reproduced at a rapid rate, which was indicated by a sharp increase in $\mathrm{OD}_{600}$ values. Figure 2 shows that the maximum growth rate was observed between 16 and $36 \mathrm{~h}$.

\section{PCR identification of $16 \mathrm{~S}$ rDNA and phylogenetic analysis of isolate RH5}

A $1.5-\mathrm{kb} 16 \mathrm{~S}$ rDNA fragment obtained by PCR was sequenced, and phylogenetic analysis based on $16 \mathrm{~S}$ rDNA gene sequences suggested that isolate RH5 formed a phylogenetic lineage with members of the genus Acinetobacter and demonstrated the maximum 16S rDNA similarity of $99 \%$ with Acinetobacter calcoaceticus as shown in Fig. 3. The isolate RH5 was, therefore, found to be a member of Acinetobacter genus and named Acinetobacter sp. RH5.

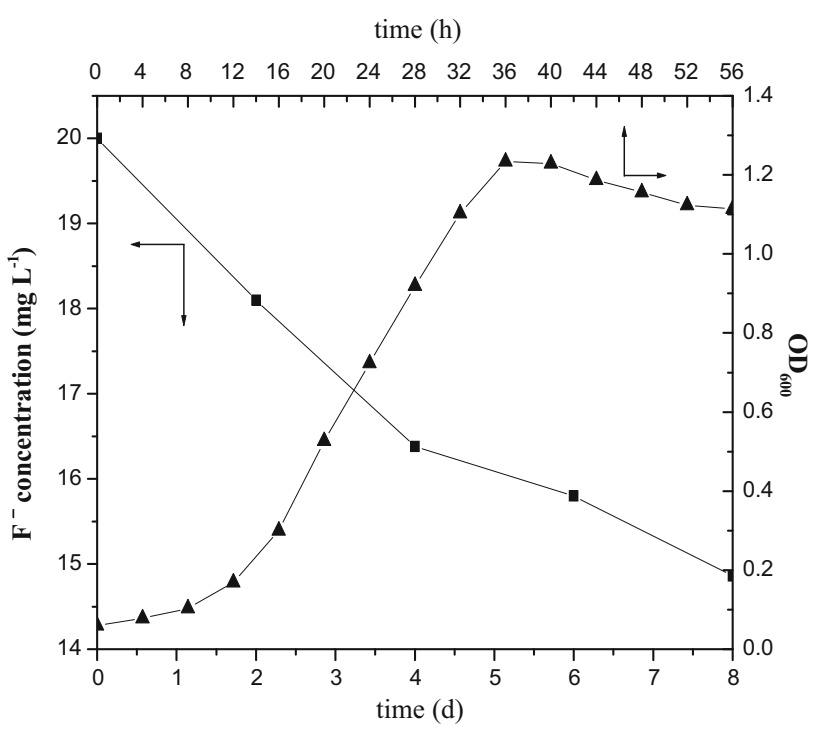

Fig. 2 Growth and fluoride removal efficiency of Acinetobacter sp. RH5; lag phase lasted for $6 \mathrm{~h}$; fluoride concentration decreased rapidly till fourth day after which retardation in the fluoride removal rate was encountered

Bioremediation of toxic xenobiotics has many advantages over other techniques as it is cheap and non-destructive. Many studies have confirmed that microbes have high affinity for metals and non-metals through a variety of mechanisms. As reported by Doble and Kumar (2005), certain bacterial species secrete high-affinity anion-binding compounds called ionophores. These ionophores bind to certain specific forms of anions and make a complex that can be utilized by the bacteria. So, the reduction in the 
Fig. 3 Phylogenetic analysis of isolate RH5 and related species

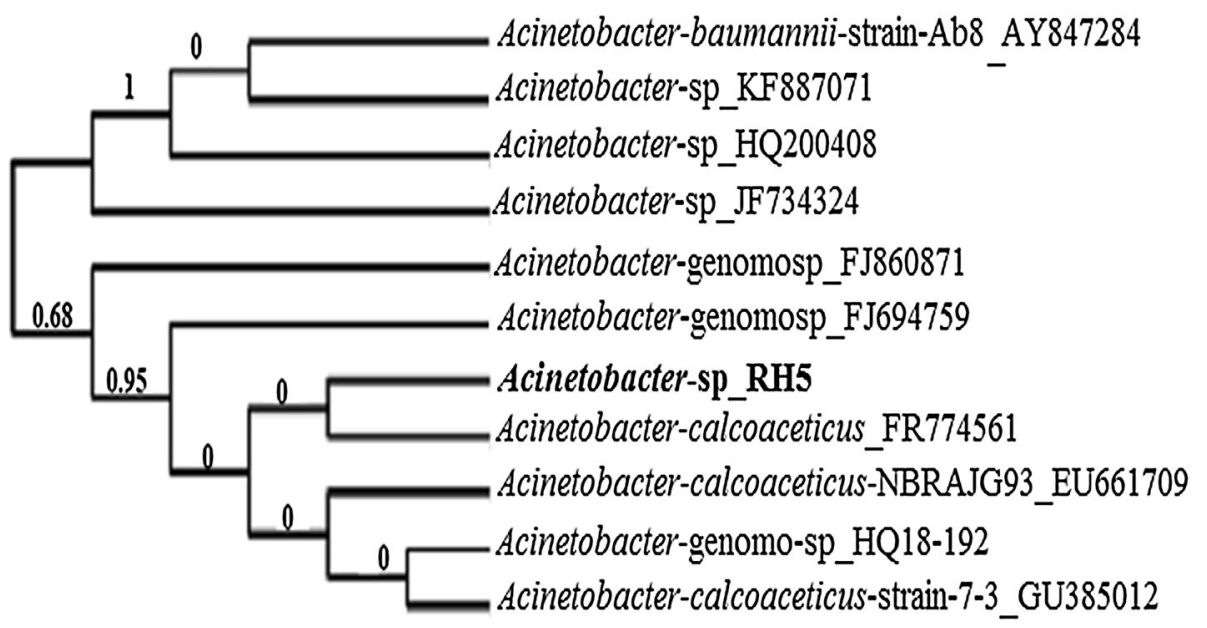

fluoride concentration of the media in our present study can be attributed to this fact. Fluoride mostly exists with a proton (HF). Hydrogen fluoride can readily cross cell membrane and acts like a proton conductor. In this way, micro-organisms having the adapting mechanisms concentrate fluoride from the surroundings making it less available in the environment.

\section{Conclusions}

Through the current study, it can be convincingly implied that the problem of fluoride contamination can be alleviated by use of bioremediation technologies. Acinetobacter sp. RH5 had better defluoridation capability than other isolates obtained from natural and anthropogenic sources for defluoridation of water. The isolate showed maximum resistance to fluoride as well as the maximum fluoride removal capability of $25.7 \%$ at $30{ }^{\circ} \mathrm{C}$. The growth characteristics were tested for a wide $\mathrm{pH}$ range, wherein $\mathrm{pH} 7$ exhibited maximum growth of isolate RH5. The strong adaptability of strain RH5 to high concentration of fluoride made it a promising candidate for treating fluoride contaminated water. Though this study dwelt only in the realm of identifying fluoride removal capabilities of bacteria, still it can be worthwhile to infer that development of a bioremediation system for defluoridation can be achieved either by immobilization of Acinetobacter sp. RH5 to prevent washing away by flowing water, or by use of sequence batch reactors to achieve longevity and maintenance of the bacteria. In order to determine the sustainability and pragmatism of the bioremediation process, further experiments are being conducted.

Acknowledgments The authors express their gratitude to Anoar Ali Khan and Sumit Hanspal Dhawane, PhD scholars of Department of Chemical Engineering, National Institute of Technology Durgapur,
India, for their enthusiastic support and cooperation during execution of the work. The financial assistance from Department of Biotechnology, Government of West Bengal, India, through research project BT (Estt.) R \& D-23/13 is gratefully acknowledged. The authors are also thankful to Department of Earth and Environmental Studies, National Institute of Durgapur, for providing the instrumental facilities towards successful completion of the project.

Open Access This article is distributed under the terms of the Creative Commons Attribution 4.0 International License (http:// creativecommons.org/licenses/by/4.0/), which permits unrestricted use, distribution, and reproduction in any medium, provided you give appropriate credit to the original author(s) and the source, provide a link to the Creative Commons license, and indicate if changes were made.

\section{References}

Ahmad S, Shamaan N, Arif N, Koon G, Shukor M, Syed M (2012) Enhanced phenol degradation by immobilized Acinetobacter sp. strain AQ5NOL 1. World J Microbiol Biotechnol 28:347-352

Annadurai ST, Rengasamy JK, Sundaram R, Munusamy AP (2014) Incidence and effects of fluoride in Indian natural ecosystem: a review. Adv Appl Sci Res 5(2):173-185

Bhattacharya HN, Chakrabarti S (2011) Incidence of fluoride in the groundwater of Purulia District, West Bengal: a geo-environmental appraisal. Sci Corresp 101(2):152

Cail B, Hanl Y, Liu B, Renl Y, Jiang S (2003) Isolation and characterization of an atrazine-degrading bacterium from industrial wastewater in China. Lett Appl Microbiol 36:272-276

Campbell W, Song HP, Barbier G (2006) Nitrate reductase for nitrate analysis in water. Environ Chem Lett 4:69-73

Chouhan S, Tuteja U, Flora SJS (2012) Isolation, identification and characterization of fluoride resistant bacteria: possible role in bioremediation. Appl Biochem Microbiol 48(1):43-50

Chung TP, Tseng HY, Juang RS (2003) Mass transfer effect and intermediate detection for phenol degradation in immobilized Pseudomonas putida systems. Process Biochem 38:1497-1507

Dahi E, Mtalo F, Njau B, Bregnhj H (1996) Defluoridation using the Nalgonda technique in Tanzania, reaching the unreached: challenges for the 21st century. In: 22nd WEDC conference, New Delhi 
Daifullah AAM, Yakout SM, Elreefy SA (2007) Adsorption of fluoride in aqueous solutions using $\mathrm{KMnO}_{4}$-modified activated carbon derived from steam pyrolysis of rice straw. J Hazard Mater 147:633-643

Datta AS, Chakrabortty AA, De Dalal SS, Lahiri SC (2014) Fluoride contamination of groundwater in West Bengal, India. 47(3):241-248

Diawara CK, Diop SN, Diallo MA, Farcy M, Deratani A (2011) Performance of nanofiltration (NF) and low pressure reverse osmosis (LPRO) membranes in the removal of fluorine and salinity from brackish drinking water. J Water Resour Protect 3:912-917

Doble M, Kumar A (2005) Biotreatment of industrial effluents. Elsevier, New York

Edmunds WM, Smedley PL (2013) Essentials of medical geology, revised edition. Springer, Berlin

Evans JB, Kloos EW (1972) Use of shake cultures in a semisolid thioglycolate medium for differentiating staphylococci from micrococci. Appl Microbiol 23(2):326-331

Ghorai S, Pant KK (2005) Equilibrium, kinetics and breakthrough studies for adsorption of fluoride on activated alumina. Sep Purif Technol 42(3):265-271

Ghosh A, Mukherjee K, Ghosh SK, Saha B (2013) Sources and toxicity of fluoride in environment. Res Chem Intermed 39(7):2881-2915

Gopalakrishnan S, Narasimhan S, Seenipandian C (1991) Incidence of fluorosis in 10 villages near Tuticorin-suggestions for prevention and control. Ind J Environ Protect 11(2):118-123

Gupta AB, Gupta SK (2001) Simultaneous carbon and nitrogen removal from high strength domestic wastewater in an aerobic RBC biofilm. Water Res 35:1714-1722

Gupta S, Mondal D, Bhardhan A (2012) Geochemical provenance and spatial distribution of fluoride in groundwater in parts of Raniganj coal field, West Bengal, India. Arch Appl Sci Res 4(1):292-306

Halder GN, Sinha K, Dhawane S (2014) Defluoridation of wastewater using powdered activated carbon developed from Eichhornia crassipes stem: optimization by Response surface methodology. Desalin Water Treat. doi:10.1080/19443994.2014.942375

Juwarkar AA, Yadav SK (2010) Bioaccumulation and biotransformation of heavy metals. In: Fulekar MH (ed) Bioremediation technology. Springer, Amsterdam, pp 266-284

Kleinubing SJ, da Silva EA, da Silva MGC, Guibal E (2011) Equilibrium of $\mathrm{Cu}$ (II) and $\mathrm{Ni}$ (II) biosorption by marine alga Sargassum filipendula in dynamic system: competitiveness and selectivity. Bioresour Technol 102(7):4610-4617

Li Y, Liang C, Slemenda CW, Ji R, Sun S, Cao J, Emsley C, Ma F, Wu Y, Ying P, Zhang Y, Gao S, Zhang W, Katz B, Niu S, Cao S, Johnston C (2001) Effect of long-term exposure to fluoride in drinking water on risks of bone fractures. $\mathrm{J}$ Bone Miner Res 16(5):932-939

Liu YJ, Zhang AN, Wang XC (2009) Biodegradation of phenol by using free and immobilized cells of Acinetobacter sp. XA05 and Sphingomonas sp. FG03. Biochem Eng J 44:187-192
MacFaddin JF (1980) Biochemical tests for identification of medical bacteria, 2nd edn. Lippincott Williams \& Wilkins, Philadelphia

McDonagh MS, Whiting PF, Wilson PM, Sutton AJ, Chestnutt I, Cooper J, Misso K, Bradley M, Treasure E, Kleijnen J (2000) Systematic review of water fluoridation. Br Med J 321:855-859

Messaitfa A (2008) Fluoride contents in ground waters and the main consumed foods (dates and tea) in Southern Algeria region. Environ Geol 55:377-383

NIOSH (1994) Manual of analytical methods (NMAM), 4th edn, $8 / 15 / 94$

Palitzsch S (1911) Application of methyl-red to the colorimetric estimation of hydrogen ion concentrations. Biochem $\mathrm{Z}$ 37:131-138

Pandey PK, Pandey M, Sharma R (2012) Defluoridation of water by a biomass: Tinospora cordifolia. J Environ Protect 3:610-616

Saha S (1993) Treatment of aqueous effluent for fluoride removal. Water Res 27(8):1347-1350

Samatya S, Yüksel U, Yüksel M, Kabay N (2007) Removal of fluoride from water by metal ions $\left(\mathrm{Al}^{3+}, \mathrm{La}^{3+}\right.$ and $\mathrm{ZrO}^{2+}$ ) loaded natural zeolite. Sep Sci Technol 42:2033-2047

Saxena VK, Ahmed S (2003) Inferring the chemical parameters for the dissolution of fluoride in groundwater. Environ Geol 43:731-736

Schamschula RG, Sugar E, Un PSH, Toth K, Armes DEB, Adkins BL (1985) Physiological indicators of fluoride exposure and utilization: an epidemiological study. Community Dent Oral Epidemiol 13:104-107

Singh PP, Barjatiya MK, Dhing S, Bhatnagar R, Kothari S, Dhar V (2001) Evidence suggesting that high intake of fluoride provokes nephrolithiasis in tribal populations. Urol Res 29(4):238-244

Sud D, Mahajan G, Kaur MP (2008) Agricultural waste material as potential adsorbent for sequestering heavy metal ions from aqueous solutions-a review. Bioresour Technol 99:6017-6027

Susheela AK (1999) Fluorosis management programme in India. Curr Sci 77(10):1250-1256

WHO (2006) Chemical fact sheets: fluoride, guidelines for drinking water quality (electronic resource), 3rd edition. Incorporation first addendum, recommendations. WHO, Geneva, vol 1, pp 375-377

Wuertz S, Mergeay M (1997) The impact of heavy metals on soil microbial communities and their activities, Modern Soil Microbiology. Marcel Dekker Inc, New York, pp 607-643

Xu J, Song XA, Zhang Q, Pan H, Liang Y, Fan XW, Zhi Y (2011) Characterization of metal removal of immobilized Bacillus strain CR-7 biomass from aqueous solutions. J Hazard Mater 187:450-458

Zhang C, Zhang W, Xu J (2013) Isolation and identification of methanethiol-utilizing bacterium CZ05 and its application in bio-trickling filter of biogas. Bioresour Technol 150:338-343

Zhu C, Bai G, Liu X, Li Y (2006) Screening high fluoride and high arsenic drinking water and surveying endemic fluorosis and arsenism in Shaanxi province in western China. Water Res 40:3015-3022 